Maurer School of Law: Indiana University

Digital Repository @ Maurer Law

1975

\title{
The Legal Process in Foreign Affairs: Military Intervention - A Testing Case
}

Thomas Ehrlich

Indiana University School of Law

Follow this and additional works at: https://www.repository.law.indiana.edu/facpub

Part of the International Law Commons, Military, War, and Peace Commons, and the Peace and Conflict Studies Commons

\section{Recommended Citation}

Ehrlich, Thomas, "The Legal Process in Foreign Affairs: Military Intervention -- A Testing Case" (1975).

Articles by Maurer Faculty. 1794.

https://www.repository.law.indiana.edu/facpub/1794

This Article is brought to you for free and open access by the Faculty Scholarship at Digital Repository @ Maurer Law. It has been accepted for inclusion in Articles by Maurer Faculty by an authorized administrator of Digital Repository @ Maurer Law. For more information, please contact rvaughan@indiana.edu. 


\section{The Legal Process in Foreign Affairs: Military Intervention-a Testing Case*}

\section{Thomas Ehrlich $\dagger$}

In the wake of the United States intervention in Cambodia in April I970, Secretary of State Rogers sent a memorandum to his departmental advisers urging that, "When crises occur in any area of the world, those in the Department who are most directly involved should be careful to ensure that the legal implications are not overlooked."1 Secretary Rogers urged particular care in situations involving the potential use of United States armed forces. The memorandum was sent in response to criticisms, in Congress and elsewhere, that legal advice had not been sought in advance of United States ground action in Cambodia. The absence of any references to legal issues in the published portions of the Pentagon Papers suggests that the failure was not limited to the Cambodian affair.

This paper suggests procedures by which law may be brought to bear on the process of deciding whether and how to use United States military force short of full-scale war. Particular attention is focused on foreign civil strife, for in the past-and predictably in the future-most decisions by our government on whether to use force have involved such conflicts. ${ }^{2}$

This area of foreign policy is perhaps the most difficult for the legal process. The reason for the difficulty is less the significance of decisions to intervene than the character of the factors involved in the decisions. The United States Government decision in Ig68 to support trade preferences for developing countries had a greater impact on our national interestshowever defined-than the 1965 decision to land troops in the Dominican

- Collaborative efforts with Professor Abram Chayes of Harvard Law School and Professor Andreas F. Lowenfeld of New York University School of Law stimulated many of the themes suggested here. Particular thanks are due to Professor Lowenfeld and to my colleagues Professor John Barton and Professor John Henry Merryman for helpful comments on the Essay in draft form. Finally, I owe a special debt to Professor Alexander George of Stanford for his creative work on decisionmalsing in foreign affairs.

+ A.B. I956, LL.B. I959, Harvard University. Richard E. Lang Dean and Professor of Law, Stanford University.

I. N.Y. Times, June 24,1970 , at 3 , cols. $3-5$.

2. By civil strife, I mean armed conflict in which the combatants are nationals of a singie state. The civil wars in France during the I8th century, in the United States during the Igth century, and in Spain, the Congo, Nigeria, and Yemen during the last two decades are all examples.

In recent years, many scholars have tried to categorize various types of civil strife. In my view, the framework proposed by Professor Richard Falk is particularly useful. See Falk, Introduction, in The INTERNatTonal LAW of CTVIL WAR (R. Falk ed. I97I). These categorizations are needed to analyze the legitimacy under international law of foreign interventions. For the purposes of this paper, however, such a typology is unnecessary. 
Republic. But the factors relevant to intervention issues are both less measurable and less rational than those involved in formulating trade policies. Trade benefits and costs can be measured in ways that are not perceived as possible when the question is whether to send in the marines.

Precisely because of this reality, crises that may lead to the use of force provide a testing case for the legal process in decisionmaking on United States foreign policy. If law and lawyers can have a significant impact in this area, then other areas are a fortiori cases.

Although the Vietnam intervention is fresh in our minds, United States military interventions in other lands have occurred mainly within Central America and the Caribbean area. President Theodore Roosevelt issued his famous corollary to the Monroe Doctrine in I904:

Chronic wrongdoing, or an impotence which results in a general loosening of the ties of civilized society, may in America, as elsewhere, ultimately require intervention by some civilized nation, and in the Western Hemisphere the adherence of the United States to the Monroe Doctrine may force the United States, however reluctantly, in flagrant cases of such wrongdoing or impotence, to the exercise of an international police power.

Within the next decades, United States marines landed in Cuba, the Dominican Republic, Haiti, and Nicaragua. In each case, what began as a temporary measure turned into a long-term occupation. In each case, United States armed presence was deeply resented. To some Latin American eyes, the United States had made the hemisphere safe from European intervention to preserve the domain for its own.

The pattern of United States military actions that lasted until its replacement by President Franklin Roosevelt's Good-Neighbor policy was generally consistent with traditional international law. Indeed, that pattern-and the pattern of interventions by other Western countries-established the tradition that made the law.

The standard learning ${ }^{3}$ is that a nation may aid, in any form it chooses, a regime battling against an "insurgency," but aid to insurgents is precluded as a violation of national sovereignty. Only when and if an insurgency develops into a "belligerency" may a country grant recognition and assistance to the rebels. But the factual premises and normative standards for determining belligerency have never been very clear, and the special nature of recognition further confuses the matter. More troublesome, unilateral determinations by intervening nations have been the rule. Countries that did

3. See, e.g., 2 L. OPPENHEIM, INTERNatTonaL LaW $\S 298$, at 660 (7th ed. 1952). 
not choose to participate in a conflict could remain neutral. Detailed codes were developed in respect to shipping-where neutrals needed special protection.

The United States usually intervened on the side of the regime in power prior to a civil strife. When this country acted on the side of the rebels, a unilateral declaration of belligerency by the rebels could obviate any problem. Even then, a few troublesome cases arose. Our Ig03 involvement in Panama is an unhappy example.

The legal norms with which the legitimacy of particular interventions were traditionally debated are of little utility today. "Sovereignty," "recognition," "insurgency," and "belligerency" were among the key standards. None is of much help, for three interrelated reasons.

First, they appear subject to manipulation in the extreme; whether they are in fact manipulated in any particular case may be less significant than the appearance. A legal norm cannot have much impact if it is viewed as verbal ammunition for either side in a dispute. The meaning of these concepts is clear to some statesmen and scholars, but their clarity is confusion in the eyes of others.

Second, the issues arise so seldom and in contexts so dissimilar that little is possible in the way of reasoned elaboration. "Due process" inherently is no less malleable a term than "sovereignty." But thousands of cases before hundreds of courts have, over time, given substance to the phrase. There are far fewer civil wars, fortunately, and the cultural, political, and social settings are usually sharply different.

Finally, the bias of these concepts toward the status quo is so strong that international law has not provided a modern framework for changing the dimensions of legitimate international activity in this area. Such a framework is essential.

By almost any test, the standard dogma of international law-that an incumbent regime is the only legitimate recipient of assistance-is inadequate in the current world. The case against those traditional rules has been made and remade with persuasiveness and eloquence. ${ }^{5}$ Yet I suspect

4. In March 1903, the legislature of Colombia rejected an agreement authorizing the United States to construct an isthmian canal. The next month a group of Panamanian residents planned the secession of Panama from Colombia, with at least the tacit support of the United States Government. On October 9, 1903, United States warships were ordered to prevent Colombian troops from landing in the erent of a revolt. And on November 3, Secretary of State Hay cabled the United States Consul in Panama: "Uprising on Isthmus reported. Keep the Department fully informed." The Consul replied: "No uprising yet. Reported it will be in the night." The revolution did begin that night and succeeded within a few hours. The Republic of Panama declared its independence on November 4, and the United States recognized the new nation 2 days later. By prearrangement, the Panamanian regime immediately negotiated a new canal treaty that was more favorable to the United States than the previous agreement. See S. Morison, The Oxford History of the American People 825 (I965).

5. See, e.g., R. Falk, Legal Order in a VIozent World IO9-55 (r968); Farer, Harnessing Rogue Elephants: A Short Discourse on Intervention in Civil Strife, 83 HARv. L. REv. 5 II (I969); 
that the strength of the rules is often underestimated. They are deeply rooted in the psychology of leadership as well as in history. It is much easier for a head of state to explain his government's aid to an existing and therefore "legitimate" foreign regime than to defend aid to foreign insurgents.

The extent of acrimony in the seemingly endless debates of the United Nations Committee on Friendly Relations must give pause to even the most optimistic postulator of new rules. Whether the proposed norms are uniformly endorsed, like "self-determination," or uniformly condemned, like "intervention," the search for agreement on the meaning of such terms has been tortuous. The General Assembly has passed a lengthy resolution that includes a series of hortatory statements concerning the impermissibility of foreign intervention in civil strife. ${ }^{6}$ But the very arguments over the meaning of that resolution, in and out of the General Assembly, make it doubtful that the Assembly or any other United Nations organ will produce agreed standards that are both general enough to find broad acceptance and specific enough to have operational consequences.

If agreed norms in this area emerge at all, I suspect they will evolve through case-by-case developments within the broad rubric of Article 2(4) of the United Nations Charter. Its terms provide: "All Members shall refrain in their international relations from the threat or use of force against the territorial integrity or political independence of any state, or in any other manner inconsistent with the Purposes of the United Nations."

This prediction, if it is accurate, puts a great premium on the development by individual nations of procedures for giving content over time, on a case-by-case basis, to the broad prohibition in Article 2(4). Many have commented that the prohibition is in danger of disregard whatever the issue. Certainly this is true in the field of foreign intervention. Yet new normative content can be developed in this area. It must be. What procedures within our own government may be helpful in developing that content?

When decisions arise concerning potential United States military intervention, the problems inherent in a centralized foreign policymaking procedure are accentuated. Policymakers generally have little difficulty in per-

Higgins, Internal War and International Law, in 3 THE Future of THE INTERNational Legal ORder 8r (C. Black \& R. Falk eds. I97I).

6. G.A. Res. 2I3I, 20 U.N. GAOR Supp. I4, at II, U.N. Doc. A/6014 (I965). After Io years of debate, the Special Committee on the Question of Defining Aggression finally reached agreement on the text of a draft definition. N.Y. Times, Apr. 13, I974, at 6, cols. 3-4. The draft marks an important step in developing international agreement on the meaning of "aggression." But its terms inevitably will trigger controversies when applied to specific events. Unfortunately, no disputesettlement mechanisms are included in the draft to resolve those controversies. 
ceiving that an external event or development will damage United States interests. The costs and risks to those interests usually are more apparent than the costs and risks of preventive action. As a result, a consensus favoring action may emerge prematurely. Perceived needs for secrecy and speed generally mean that only a few advisers are involved. ${ }^{7}$ The customary checks and balances at work in major decisions on domestic policy-Medicare, air pollution, and the like-are largely absent. Perhaps more critical, no adversary process is at work to ensure full articulation of differing interests and perspectives.

If nothing else is clear it should be that more lawyers in government are not the solution. Some writers (including Dr. Kissinger before he was in office) have suggested that lawyers are often part of the problem-that the legal backgrounds of Secretaries Dulles, Rusk, and Rogers, and others as well, have made them overly concerned with questions of "obligation," and "commitment," or at least overly willing to turn time-bound statements of policy into permanent undertakings imbued with legal implications. ${ }^{8}$ But the issue here is not lawyers but legal arrangements.

Legal factors certainly should not be the sole determinant of policymaking in any area of political importance, any more than military, economic, or other factors ought to be the sole determinant. Legal issues ought to be a part of the decisionmaking process, however, and I am concerned because those issues seem to receive relatively short shrift, particularly when military intervention is at issue. The case for that concern is not hard to document. It was true in late Igth-century and early 2othcentury foreign policymaking by the United States Government toward Latin America. It was true in the 1965 Dominican Republic crisis. It was true in the I970 decision to send United States troops into Cambodia. It was true in these and other instances because the existing international norms were inadequate on their substantive merits and self-defining in their procedural applications. Any nation can decide for itself when and if a particular civil strife in some foreign land moves from a rebellion to an insurgency to a belligerency. And there has been no machinery within the United States Government to develop new standards adequate to a new age.

I have no mechanical rabbits to suggest for meeting this challenge. But I believe that important benefits will emerge from attention to ways of promoting advocacy of divergent legal views among government and private lawyers. These benefits are not exclusively related to military inter-

7. See generally Kazenbach, Foreign Policy, Public Opinion and Secrecy, 52 ForeIGN AFF. I (1973).

8. See G. Kennan, American Diplomacx I900-1950, at 96-I0o (r95I); Kissinger, The Viet Nam Negotiations, 47 FOREIGN Afr. 211, 222-23 (1969). 
vention, but they have "testing case" relevance in that context. Three lines of approach seem most promising-within the executive; within the Congress; and within the legal profession.

In recent years, a number of case studies have been published concerning United States decisionmaking on whether to use force (and, if so, how much force) abroad. ${ }^{9}$ These studies compel the judgment, in my view, that more and better arrangements are needed within the executive branch to ensure what Professor Alexander George has called "multiple advocacy" before the President and Secretary of State. ${ }^{10}$ Professor George presents a persuasive case that effective and reasoned decisionmaking is more likely to result when different perspectives are not blurred in the bureaucratic process of preparing the foundation for a presidential decision. President Roosevelt developed a staff of advisers on whom he could count to raise opposing positions and to maintain those positions until the issue reached his desk. The clashes between Harold Ickes and Harry Hopkins are a prime example. Similarly, former Secretary of State Dean Acheson stressed the extent to which President Truman encouraged different offcials to bring their different views to him for resolution. ${ }^{11}$

None of the existing formal arrangements in the executive branch is designed to promote this sort of multiple advocacy concerning the legal implications of United States military intervention. The Legal Adviser to the State Department is responsible for considering those implications. But he is also, and primarily, charged with being an advocate for the Department-with defending, in legal terms, the Department's ultimate judgment, whatever that may be.

Some have suggested a legal adviser on international affairs reporting directly to the President. ${ }^{12}$ Such an official would weigh the legal aspects of alternative interventionary decisions in terms of developing a sound body of international law, An alternative model, differing more in theory than in practice from the first, calls for a kind of devil's advocate with a man-

9. See, e.g., R. Falk ed., supra note 2; W. Kane, Crvil Strife in Latin AMrerica: A Legai HistoRY OF U.S. INVOLVEMENT (I972).

ro. George, The Case for Multiple Advocacy in Making Foreign Policy, 66 AM. Por. Scr. Rev. 75I (1972). See also Destler, Comment: Multiple Advocacy: Some "Limits and Costs," 66 AM. PoL. Scr. Rev. 786 (1972); George, Rejoinder to "Comment" by I. M. Destler, 66 AMr. PoL. Scr. Rev. 79 I (1972).

ix. See D. Acheson, Present at the Creation 733 (I969): "The President gives his hierarchical blessing to platitudes. To perform his real duty must involve the anguish of decision, and to decide one must know the real issues. These have to be found and flushed like birds from a field. The adversary process is the best bird dog."

12. See Falk, Law, Lawyers, and the Conduct of American Foreign Relations, 78 Y YLE L.J. 919, 933 (I969). 
date to establish an adversary proceeding on the legal implications of alternative proposals. ${ }^{13}$ This arrangement would ensure some debate on the law involved in proposed actions. It would reduce the risks that the sharp corners of controversy would be smoothed off as proposals move up a bureaucratic ladder.

The arrangement would have major advantages, but its dangers are obvious. Most important, a devil's advocate too easily could become just that-an advocate of the devil, not a serious proponent of a serious position. Others involved in a particular decision could listen to his arguments with the comfortable knowledge that he was "only doing his job," and was not to be taken seriously.

Another approach would be less mechanical but probably more effective. It would establish within the State Department not a formal mechanism to promote debate from differing perspectives but rather a policy to encourage it. The Legal Adviser would be called on, as a matter of publicly announced policy, to ensure that advocates within-or, if necessary, outside-his office developed the strongest possible legal arguments for conflicting positions. In some situations, this adversary process might involve only two sides; more often, a number of choices should be developed. I am fairly convinced that within a reasonably short time, a practice of preparing opposing legal briefs could become well-ingrained. The value of such a practice could be substantial. It would promote reasoned analysis of legal positions in a way that is unlikely without adversary pressures.

The advantages of multiple-advocacy arrangements are not, of course, limited to lawyers or to legal matters. International trade issues, for example, can be sharpened and clarified by a clash of economists with differing views. The same is true of experts in other disciplines. Further, there is often much to be gained-and little to be lost-from bringing together practitioners in various fields. Coordination is needed to ensure that the clash elucidates rather than clouds an issue. And this is often difficult. But the benefits can be substantial.

Without minimizing the importance of other substantive perspectives, I focus here on law both because it seems to me relatively neglected in foreign policy and because the procedures for ensuring multiple advocacy are themselves part of the legal process in national decisionmaking on foreign affairs.

As Professor George recognizes, the design of multiple-advocacy ar-

13. Some have suggested that Undersecretary of State George W. Ball played this role (although not directly regarding legal issues) in the mid-rg60's debates on United States policy regarding Southeast Asia. See D. Halberstans, The Best and the Brightest 49 I-99 (I972). 
rangements can raise formidable bureaucratic problems, especially at administrative levels below that of the Presidential staff. In terms of procedure, the Legal Adviser would need an assistant to coordinate the advocacy-one with adequate leverage to ensure balanced analysis. In terms of substance, those involved would have to resist the temptation to limit debate to two positions. But I believe that these and other problems could be overcome and that the results would be more than worth the effort.

The arguments advanced by the Legal Adviser in support of the Ig65 Dominican intervention illustrate the dangers of an ex cathedra approach. In April I965, a military coup overthrew the regime of President Reid Cabral. Almost immediately, the United States landed its troops. The State Department initially defended the intervention on the ground that the troops were necessary to protect the lives of United States and other foreign nationals. Rather quickly, however, the stated rationale shifted to a claim that the United States action was necessary to forestall a Communist takeover. The Legal Adviser's Office was not substantially involved or consulted either before the intervention or immediately thereafter. It was not until May 5, I965-more than a week after the landing of American marines-that the Legal Adviser released a brief on The Legal Basis for U.S. Actions in the Dominican Republic. ${ }^{14}$ The opinion was prepared because of intense pressure from outside the executive branch, particularly within Congress, for some statement about the law of the matter.

In my view, the Dominican intervention was a tragic mistake. But even after the United States decision to use force, much might have been done by lawyers. If the opportunity had been available for the Legal Adviser's Office to prepare opposing legal arguments-to take advantage of the clash of opinions-before or during the crisis, I have no doubt that the most persuasive case in support of intervention would have been framed exclusively in terms of protecting United States citizens and, perhaps, foreign nationals, much as was done in the Congo rescue operation. ${ }^{15}$ One can question whether the United States should ever intervene militarily to save its own citizens on foreign shores, but there is substantial support for such action in traditional international law. A publicly announced legal position along this line might have put some brake on United States involvement in succeeding days, when it became clear that United States citizens and other non-Dominicans were safe. A policy to ensure a clash of opposing legal positions would almost certainly have produced that result.

The actual opinion of the Legal Adviser seems to conclude that uni-

14. See Dep't of State, Memorandum: Legal Basis for U.S. Actions in the Dominican Republic, in III CoNG. Rec. IIIIg (I965). The final version was revised on May 7 , to take into account the May 6 resolution of the OAS.

15. See Ehrlich, The Measuring Line of Occasion, 3 Stan. J. INT't Studies 27, 35 (rg68). 
lateral military intervention is appropriate whenever any one of three circumstances exists-whenever nationals of any foreign country are in danger; whenever it is possible that a regional organization might act; and whenever Communists are involved. I have suggested elsewhere a legal analysis that, in my view, would have been more persuasive and would have created a narrower precedent ${ }^{16} \mathrm{My}$ point here is that if the legal arguments put forth to defend the action had been subject to adversary debate before the event, the intervention might not have occurred; orif it had-the precedent could have been sharply narrowed. Such bad lawyering weakens not only the position of the United States in world affairs, but the position of international law as well.

Another unhappy illustration of the same point is a memorandum issued by the Secretary of State on May I, I973, in defense of continued United States bombing of Cambodia, ${ }^{17}$ notwithstanding the cease-fire agreement negotiated with North Vietnam 3 months earlier. ${ }^{18}$ Article 20 of that agreement calls for the withdrawal of all foreign armed forces from Cambodia. The air strikes on Cambodia represented, according to the memorandum, "a meaningful interim action to bring about compliance with this critical provision in the Vietnam agreement."

The opinion was released only after intense pressures by the Congress for some executive branch legal analysis of the air strikes. In prior weeks, justification by the State Department had been demanded, but the Department had refused. Finally, the opinion was issued. In this case, I know of no sound way in which the United States' actions could be defended in law. The argument that one nation's alleged violation of its commitment provides legal support for bombing another country cannot withstand analysis in international law. The opinion was widely viewed by legal scholars as well as by Congressmen as unpersuasive.

The very fact that no credible legal case could be made for the United States actions may have helped to convince some Congressmen that the bombing should be halted-even though cessation required a step by Congress that had never previously been taken. ${ }^{10}$ If the Legal Adviser's Office had been required much earlier to state publicly the basis in law for the United States action-to prepare a kind of legal prospectus-the action

I6. Id. at 36 .

17. N.Y. Times, May I, I973, at I0, cols. 3-8.

18. The cease-fire agreement is printed in 68 Dep'T STATE Bull. 169 (1973).

19. See Second Supplemental Appropriations Act $\$ 307,87$ Stat. 99 (I973): "None of the funds herein appropriated under this Act may be expended to support directly or indirectly combat activities in or over Cambodia, Laos, North Vietnam and South Vietnam or of the shores of Cambodia, Laos, North Vietnam and South Vietnam by United States forces, and after August 15, I973, no other funds heretofore appropriated under any other Act may be expended for such purpose." The Act was passed and signed by President Nixon after his veto of a version calling for an immediate cutoff of funds was sustained. See I973 U.S. CoDE Cong. \& AD. News I985 (President's veto message). 
might have been avoided or terminated sooner. At the least, it would have been subject to more searching legal analysis than actually occurred.

By contrast, the Cuban missile crisis illustrates the advantages of affirmative efforts to explore various approaches to particular legal issues. ${ }^{20}$ It shows the substantial role that law and lawyers can have in even the most volatile emergency if a multiple-advocacy process is encouraged. Over the course of the 13 -day period in which competing strategies were debated within the President's advisory group on the crisis-a group that included a number of lawyers-conflicting legal positions were reviewed as part of the design of competing "scenarios." Those positions ranged from that of Dean Acheson, who said that international law is essentially irrelevant at the time of such crisis, to that of Deputy Attorney General Katzenbach, who claimed that either an air strike or blockade could be supported under international law as self-defense, to that of Acting Legal Adviser Meeker, who argued that the only use of force justifiable in law was a quarantine, and further that a quarantine was valid only if backed by the Organization of American States. ${ }^{21}$

The point here is the value of multiple advocacy of opposing views. The details of various arrangements to promote such advocacy are less significant than that some arrangements exist. Indeed the advantages may be maximized when a number of different arrangements are used. ${ }^{22}$

\section{III}

It is, in my view, even more important that new governmental arrangements be encouraged outside the executive branch. As a practical matter, this means legislative arrangements, since there is little likelihood of substantial involvement by the judiciary. Courts were asked to pass on legal issues involving United States participation in the Vietnam War, but they consistently refused. On grounds of either lack of standing or the "political question" doctrine, the courts stopped short of considering the constitutional legitimacy of the war in the absence of a specific declaration of

20. See A. Chayes, The Cuban Misstre Crisis (1974).

2I. Ambassador Adlai E. Stevenson went even further and advocated removal of the United States missiles from Turkey and Greece, though published accounts are unclear whether he made that case as a matter of law or of politics.

22. Currently, public debate on intervention issues sometimes can be generated, but only with difficulty and usually well after the decision has been made. When the United States mined the harbor of Haiphong in the spring of I972, one of my colleagues and I wrote to the State Department Legal Adviser questioning the action on grounds of international law. The Legal Adviser responded, and excerpts from his response were ultimately published. 66 AM. J. INT'L L. 836 (I972). Subsequently, both our initial letter and a rejoinder were also published. 67 AM. J. INr'L L. 325 (I972). Taken together, the letter, response, and rejoinder focus and frame some of the key legal issues involved in considering the legitimacy of the United States action. Regardless of how one resolves the legal questions, most will agree that the arguments ought to have been exposed to public scrutiny, and much more quickly than was actually the case. But it took some effort to ensure that our initial letter and rejoinder to the Legal Adviser's response were also published. 
war by Congress. There are some signs that this practice may have weakened. The order by a federal district court in August 1973 to halt United States bombing in Cambodia is a significant example, though that order was reversed on appeal. ${ }^{23}$

Still, a number of important factors militate against a significant impact by the judiciary on the process of policymaking in international affairs. Concerning decisions involving the potential use of force, perhaps the most important factor is timing. Even assuming a willingness on the part of a court to review the legality of a military intervention, such review will almost certainly come only after, rather than before, the fact. Declaratory judgments are unlikely. Further, the restraints on judicial involvement in this area, developed under the "political question" rubric, make it unlikely-and many say improper-for a court to consider the constitutional issues raised by these cases. Congress is, therefore, the only governmental possibility, apart from the executive branch, for guidance on questions concerning military intervention.

In the wake of American involvement in Southeast Asia, a great deal of controversy has been focused on the meaning and implications of the constitutional provision that Congress alone may "declare war." Rather than reexamine that controversy, I turn to what seems to me a pressing requirement: that Congress widen and sharpen the debate on what the international law is and what it should be relative to any particular situation that may involve United States military intervention. Whatever arrangements are designed to encourage multiple advocacy within the executive branch, it is probable that most decisions on intervention will not be subject to a full adversary debate in that forum. But if the Congress is given the facts of a situation, and allowed some time to consider them, such debate is much more likely.

In November I973 the Congress adopted-over the President's vetoa joint resolution "Concerning the War Powers of the President and Congress." It is designed to limit the circumstances in which the President may deploy United States armed forces in foreign hostilities without legislative sanction. This was the latest round in a series of efforts begun in the Ig60's to provide statutory limits on the deployment of United States armed forces by the President in the absence of congressional authorization. The

23. The district court's ruling is found in two separate opinions: Holtzman v. Schlesinger, $36 \mathrm{I}$ F. Supp. 544 (E.D.N.Y.) (standing) and Holtzman v. Schlesinger, 36r F. Supp. 553 (E.D.N.Y.) (justiciability), rev'd, 484 F.2d I307 (2d Cir. 1973) (holding dispute political question and nonjusticiable), vacation of circuit order refused, 4 I4 U.S. 1307 (Marshall, Circuit Justice), circuit order

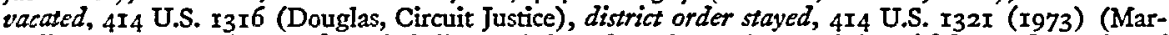
shall, Circuit Justice). See also Mitchell $\nabla$. Laird, 476 F.2d 533 (D.C. Cir.), withdrawn by Order of Court, 476 F.2d XXVIII (1973).

24. H.R.J. Res. 542, 93 d Cong., Ist Sess., II9 Cong. REc. I70 (I973). 
resolution was a compromise between the differing views of many in and out of Congress. President Nixon stated in his veto message that two key provisions in the resolution were "clearly unconstitutional."25 More than two-thirds of the Congress disagreed. The current status of those provisions is thus unclear. The constitutionality and wisdom of their terms have been argued and reargued at length. But another provision in the resolution-section 4-has particular relevance here, although it received little attention in the public debates, and no one questions its constitutionality. Within 48 hours after deploying United States armed forces in foreign hostilities, the President is required to submit a report on the circumstances and justifications of the intervention, including a legal analysis.

No one can expect preparation of a carefully reasoned, fully developed legal brief within 2 days after a decision to use military force. But precisely for that reason, the requirement can have several useful effects.

First, a reporting requirement will press government lawyers to examine the legal ramifications of possible alternative courses of action in advance of a crisis. International conflicts have occasionally occurred in which the United States could not have foreseen the likelihood of military action. But such situations are relatively rare. In most cases that have involved actual or potential uses of United States military force, policy planners had some warning; prior legal analysis would have been possible, had lawyers been consulted, just as there was contingency planning by the military and the State Department desk officers in these situations.

Second, and closely related, as a crisis develops the reporting requirement will encourage the President and his political and military advisers to involve lawyers in the process of determining whether and when to use force-and how much force to use. The need for legal justification to support the decision will be a strong incentive for analysis of legal considerations as part of the overall decisionmaking process.

The Cuban missile crisis erupted suddenly, for example, but lawyers in the State and Defense Departments had previously worked through the basic legal considerations. The presence of Soviet missiles had not been considered likely by the executive branch, but the possibility that some set of circumstances might warrant United States intervention had been

25. Message from President Nixon to the House of Representatives, Oct. 23, I973, I973 U.S. CODE CONG. \& AD. News 3808 . One of the two provisions requires withdrawal of United States forces from foreign hostilities within 60 to 90 days unless the Congress authorizes an extension. The other requires such a withdrawal immediately upon passage of a concurrent resolution by Congress. The veto message stated that both provisions are unconstitutional, that the Constitution can be altered only by amendment, and that "any attempt to make such alterations by legislation is clearly without force." President Nixon implied, therefore, that he would ignore the provisions should a situation arise in which their terms are applicable. When the resolution was adopted over the President's veto, however, the White House refused to state whether it would obey the statute in those or any other circumstances. See N.Y. Times, Nov. 8, I973, at I, col. 8. The resolution does include a severability provision. 
foreseen. As a result, preliminary legal analyses were prepared covering some of the key issues. The Legal Adviser's Office in the State Department published the basic legal justification of the quarantine within I2 hours after it was announced. ${ }^{26}$ On the whole, that justification withstood scrutiny in the period that followed. But it could not have been written in half a day without careful preparatory work.

Even in the unexpected explosion of the I973 Middle East War-when prior warnings were not available-lawyers could and should have been engaged during the war in the process of examining alternative peacekeeping arrangements. Yet, from all accounts, State Department lawyers were isolated from policymaking in the matter. ${ }^{27}$

It is true, of course, that if a President's lawyers are only clever but not wise, they can verbalize legal justifications without substantive legal content. Perhaps the reporting provision in the "war powers" resolution is better viewed, therefore, as an opportunity rather than a requirement. But it should, at the least, pressure a President and his advisers to articulate a legal basis for United States intervention and to think through that basis in advance.

It is sometimes suggested that postevent justifications are worth little. But this view misses a fundamental reality of policymaking.

[T] he requirement of justification suffuses the basic process of choice. There is continuous feedback between the knowledge that the government will be called upon to justify its action and the kind of action that can be chosen. The linkage tends to induce a tolerable congruence between the actual corporate decisionprocess, with its interplay of personal, bureaucratic, and political factors, and the idealized picture of rational choice on the basis of objectively coherent criteria. We may grant a considerable latitude for evasion and manipulation. But to ignore the requirement of justification too long or to violate its canons too egregiously creates, in a democracy, what we have come to call a "credibility gap." The ultimate consequence is to erode the capacity of the government to govern. ${ }^{28}$

Even if one concludes-erroneously, I believe-that the legal analyses required under the "war powers" resolution will have little impact on decisionmaking within the executive branch, they should still focus intervention issues within a framework that promotes public debate. One can expect the arguments to be rebutted and executive branch lawyers to re-

26. See Dep't of State, Memorandum: Legal Basis for the Quarantine of Cuba, in A. CHAYrs, T. Ehruich, \& A. Lotwenfeld, International Legai Process, Doc. Supp. $552-58$ (1968).

27. After Dr. Kissinger became Secretary of State, he appointed his personal lawyer, Carlyle $\mathrm{Maw}$, as the Department's Iegal Adviser. In spite of Dr. Kissinger's previously disparaging view of the role of lawyers in foreign affairs, see note 8 stpra and accompanying text, Mr. Maw accompanied the Secretary during most of his "shuttle diplomacy" in the Middle East, and apparently had a more significant role in peacemaking than had any Legal Adviser since Herman Phleger, who held that office when John Foster Dulles was Secretary of State.

28. A. ChaYes, supra note 20, at ro3. 
spond to the rebuttals. The process should produce far more informed analysis of policy issues in their legal dimensions than now occurs.

The resolution does not, by its terms, require congressional involvement in the analysis of intervention issues before-as opposed to afterUnited States troops are engaged in foreign hostilities. But for the reasons I have indicated the reporting requirement in the resolution should make such involvement more likely. No one can be sure, of course, how much legislative impact participation would have in any particular case. A lesson from the Indochina War of two decades ago, however, suggests that the impact can be substantial.

Until I954, all Indochina was a French colonial possession. But in the spring of that year, a bloody civil war was taking place within Vietnam. On March 20, the French Chief of Staff arrived in Washington with a message that Indochina would fall unless the United States intervened. France sought United States military action to turn the tide. Strong support for American intervention came from the Chairman of the Joint Chiefs of Staff, Admiral Radford. He viewed the potential fall of Vietnam as a first step toward the loss of Indochina and ultimately all of Southeast Asia. It was essential, he argued, that what was later called the first domino not be allowed to fall. The French forces in Vietnam would have to be buttressed by the United States.

Admiral Radford prepared a detailed plan of military action to aid the French. President Eisenhower called on Secretary of State John Foster Dulles and Admiral Radford to meet with eight congressional leadersfive senators and three representatives-to review the intervention plan. The meeting was held on April 3, I954. Radford presented his scheme and Dulles endorsed it. $^{29}$

But the congressional leaders unanimously opposed United States intervention. All agreed that the unilateral use of force by the United States would be a disaster. They insisted on a multilateral effort if any effort were to be made at all. Although the arguments were probably rooted primarily in political considerations, they might well have been framed in legal terms. Certainly the Congressmen were influenced by the multilateral support through the United Nations of the United States intervention in Korea.

There are some ironies in the whole affair, particularly that Senator

29. One recent analysis claims that Dulles really wanted to scuttle the Radford plan. See R. RANDLE, GENEVA 1954, 63-65 (1969). According to this theory, Dulles arranged the meeting with legislative leaders to prove to the United States military establishment that Congress would not permit United States intervention. This effort to make Dulles appear less of a hawk, but more of a Machiavelli, seems implausible in light of other reports of his stated support for an American use of force. Most accounts conclude that Dulles supported the Radford plan because he saw it as essential to check a Communist chain reaction through Indochina. See George, The Case for Multiple Advocacy in Making Foreign Policy, supra note Io, at 77 I n.67. 
Lyndon B. Johnson was one of the most vocal opponents of the plan. April 3, I954, has been called "The Day We Didn't Go to War" ${ }^{\text {"30 }}$ by Chalmers M. Roberts. Others have suggested that Mr. Roberts over-dramatized the confrontation with congressional leaders. But no one disputes that key figures in the executive branch were prepared to intervene and that a handful of Congressmen raised a series of counterarguments that the President found compelling. In my own view, the decision not to intervene in Indochina was correct, at least if one divorces that decision from the events of a decade later. Even if one disputes that verdict, I think it hard to dissent from the proposition that congressional judgment brought a valuable dimension to the decisionmaking process. ${ }^{31}$

Contrast the process of decisionmaking in April I954 with the process in March 1969 when the United States began to bomb Cambodia. For I3 months the intervention remained a secret from the public and from most of Congress. The President obviously knew about the massive bombings, yet in April r97o he claimed that the United States invasion at that time was the first involvement by the American military in Cambodia. Presumably, many in the State Department were wholly unaware of the United States' actions during the I3-month period. The State Department Legal Adviser stated in May I970 before a bar association meeting that the United States had not intervened until the previous month. ${ }^{32}$ It might be that most in Congress would have approved the bombing of Cambodia if it had been announced publicly in the spring of 1969 . It is conceivable that a sound legal case for the bombing could have been presented and that the case would have been accepted by Congress as by the President. But the opportunity never came. As a result, the kind of countervailing congressional pressures that prevailed in I954 never had a chance to be expressed.

The persuasive legal case that the United States made for the quarantine during the Cuban missile crisis was premised in major measure on the operation of multilateral as opposed to unilateral decisionmaking processes. The quarantine would be authorized by a regional arrangement, the Organization of American States, acting under a multilateral agreement, the Rio Treaty. It appears that in 1954 the congressional leaders advocated a similar collective approach if any action were to occur. I do not suggest that they argued primarily on the law. Whether or not the Congressmen pressed their case in terms of law, morality, or practical politics is less sig-

30. Roberts, The Day We Didn't Go to War, II THE REPORTER, Sept. I4, I954, at 3I. See also R. RaNDLE, supra note 29, at 63-65.

31. Gen. Matthew Ridgway, Army Chief of Staff, also opposed the plan, and his arguments were an important factor in the ultimate decision not to intervene.

32. Stevenson, United States Military Actions in Cambodia: Questions of International Law, 62 Dep't State Bull. 765 (I970). 
nificant than that the President found it important to seek their counsel.

Too often in the recent past there have been inadequate opportunities for such advice to be given. The "war powers" resolution is an important step forward. It underscores the desires of Congress for involvement in decisionmaking. The resolution may be a sufficient catalyst to promote congressional consultation before as well as after an intervention decision. Only experience will tell.

\section{IV}

Finally, I think that members of the legal profession have an opportunity and an obligation in this field. Unfortunately, in the realm of international law, the organized bar in general and the American Bar Association in particular are best known for their stands against American involvement in international arrangements-the Genocide Convention is a prime example. On the rare occasions when the bar in the United States has focused its attention on matters of international law, its leaders have generally been content to confine themselves to platitudes favoring world peace through world law.

An opportunity exists to do much more-to organize and promote focused debate on legal issues involving particular military interventions. Some legal institutions-local bar associations and law schools-meet this responsibility. The Association of the Bar of the City of New York, through the Hammarskjöld Forum, is a prime example. But sadly, such institutions are rare. One should not expect resolutions on the merits of intervention issues. But it is reasonable to expect that those institutions seek out qualified advocates for opposing positions and press them to present their views. Insight and understanding will emerge in the clash of opinions.

"We must not make a scarecrow of the law," wrote Shakespeare in Measure for Measure, "setting it up to fear the birds of prey, and let it keep one shape till custom make it their perch, and not their terror." ${ }^{33}$ For too long, the international law on foreign intervention has kept one shape; now there is little left but rhetoric. It is up to all of us in the legal profession to engage in the creative process of designing a new shape. In this area of law, more than others, process is substance. Creative procedures are needed to ensure reasoned deliberations on any actual or proposed new interventions. Lawyers can and should contribute to those procedures and deliberations.

33. Act $I$, scene $i$. 